\title{
HUBUNGAN ASUPAN ENERGI DAN PARITAS TERHADAP RESIKO KEK (KEKURANGAN ENERGI KRONIS) PADA IBU HAMIL DI KECAMATAN PAYUNG SEKAKI KOTA PEKANBARU
}

\author{
YESSI ALZA*
}

*Dosen Jurusan Gizi

\begin{abstract}
ABSTRAK
Kekurangan energi kronis (KEK) adalah keadaan ibu yang menderita kekurangan makanan yang berlangsung menahun (kronis) dan terjadi sebelum kehamilan sehingga mengakibatkan timbulnya gangguan kesehatan pada ibu.. Penyebab KEK secara langsung adalah akibat dari ketidakseimbangan antara asupan energi untuk pemenuhan kebutuhan dan pengeluaran energi. Selain itu, paritas $\geq 4$ dapat menguras cadangan zat gizi tubuh seorang ibu lebih banyak. Hal ini juga dapat menyebabkan beresiko KEK. Tujuan penelitian ini adalah untuk mengetahui hubungan antara asupan energi dan paritas terhadap resiko KEK pada Ibu Hamil di Kecamatan Payung Sekaki Kota Pekanbaru.

Penelitian dilaksanakan pada 10 Maret - 1 Juli 2014 di Kecamatan Payung Sekaki Kota Pekanbaru. Jenis penelitian adalah penelitian analitik dengan desain penelitian Cross Sectional. Jumlah sampel ibu hamil yaitu sebanyak 137 orang yang diambil secara Multistage Cluster Sampling dengan kelurahan dan posyandu sebagai clusternya. dari setiap kelurahan. Variabel yang diteliti yaitu asupan energi, paritas dan resiko KEK. Pengolahan data secara univariat dan bivariat dengan uji analisa Chi-Square.

Hasil penelitian menunjukkan asupan energi cukup sebanyak 13,1\%, paritas < 4 sebanyak $96,4 \%$ dan yang tidak beresiko KEK sebanyak 53,3\%. Ada hubungan yang signifikan antara asupan energi dengan resiko $\operatorname{KEK}(p=0,003)$ dan tidak ada hubungan yang signifikan antara paritas dengan resiko KEK $(p=0,371)$. Untuk memenuhi kebutuhan asupan energi ibu hamil, selama hamil dianjurkan mengatur pola makan dengan prinsip gizi seimbang sesuai kebutuhan dan sebaiknya petugas kesehatan harus memberikan penyuluhan dan informasi pada ibu hamil tentang gizi seimbang untuk ibu hamil.
\end{abstract}

Key words : Asupan Energi, Paritas, Resiko KEK

\section{PENDAHULUAN}

Arah dan kebijaksanaan pembangunan bidang kesehatan, diantaranya menyebutkan bahwa pembangunan kesehatan diarahkan untuk mempertinggi derajat kesehatan termasuk didalamnya keadaan gizi masyarakat dalam rangka meningkatkan kualitas hidup serta kecerdasan dan kesejahteraan rakyat pada umumnya (Suhardjo, 2007). Pembangunan kesehatan dilaksanakan dengan tujuan meningkatkan kesadaran, kemauan dan kemampuan hidup sehat bagi setiap orang agar terwujud derajat kesehatan masyarakat yang setinggitingginya. Dalam rangka mencapai tujuan tersebut pembangunan dilaksanakan secara sistematis dan berkesinambungan (Depkes RI, 2005).

Hasil Survei Demografi dan Kesehatan Indonesia (SDKI) 2012 menunjukkan tingkat kematian ibu meningkat tajam dibanding survei yang dilakukan 2007. Survei tersebut (SDKI 2012) menemukan terdapat kematian ibu melahirkan sebanyak 359/100.000 ribu kelahiran hidup. Padahal, pada survei 2007 angka kematian ibu hanya 228/100.000 ribu kelahiran hidup. Target Millenium Development Goals (MDGS) 2015 adalah menurunkan angka kematian ibu menjadi 102/100.000 kelahiran hidup.

Angka kematian bayi berdasarkan data survei demografi dan kesehatan 2007 adalah 34/100.000 kelahiran hidup. Sementara tahun 2012 mengalami penurunan dari sebelumnya yaitu 32/100.000 kelahiran hidup. namun belum mencapai target Millenium Development Goals (MDGS) 2015 angka kematian bayi menjadi 23/ 100.000 kelahiran hidup.

Tingginya angka kematian ibu dan angka kematian bayi berdasarkan data diatas sangat terkait dengan derajat 
kesehatan ibu, khususnya ibu hamil. Salah satu langkah yang telah diambil pemerintah untuk menurunkan angka kematian ibu dan angka kematian bayi adalah dengan upaya penanggulangan Kekurangan Energi Kronis (KEK) pada ibu hamil.

Kekurangan energi kronis (KEK) adalah keadaan ibu yang menderita kekurangan makanan yang berlangsung menahun (kronis) dan terjadi sebelum kehamilan sehingga mengakibatkan timbulnya gangguan kesehatan pada ibu. KEK dapat terjadi pada wanita usia subur dan pada ibu hamil (Wiboworini, 2007).

Resiko KEK pada ibu hamil mempunyai akibat tidak saja terhambatnya pertumbuhan janin, berat badan lahir, pertumbuhan bayi dan anak, tetapi juga mempunyai pengaruh buruk pada generasi selanjutnya. Konsekuensi KEK pada ibu hamil antara lain penyakit infeksi, persalinan lama, kematian ibu, berat bayi lahir rendah (BBLR), pendarahan, dan kematian bayi dan janin (Albugis, 2008).

Penyebab KEK adalah akibat dari ketidakseimbangan antara asupan untuk pemenuhan kebutuhan dan pengeluaran energi. Selain itu beberapa hal penting yang berkaitan dengan status gizi seorang ibu adalah kehamilan pada ibu berusia muda (kurang dari 20 tahun), kehamilan dengan jarak yang pendek dengan kehamilan sebelumnya (kurang dari 2 tahun), paritas ( $\geq 4$ orang) dan kehamilan pada usia terlalu tua (lebih dari 35 tahun) (Departemen Gizi \& Kesehatan, 2007).

Paritas adalah jumlah anak yang pernah dilahirkan oleh ibu baik lahir hidup maupun mati. Ibu hamil yang memiliki paritas $\geq 4$ dapat menguras cadangan zat gizi tubuh seorang ibu lebih banyak. Hal ini dapat menyebabkan beresiko KEK (kekurangan energi kronis) (Departemen Gizi \& Kesehatan, 2007).

Status gizi ibu hamil bisa diketahui dengan mengukur ukuran lingkar lengan atas, jika $<23,5 \mathrm{~cm}$ maka ibu hamil tersebut termasuk Kurang Energi Kronis (KEK), ini berarti ibu sudah mengalami keadaan kurang gizi dalam jangka waktu yang telah lama, bila ini terjadi maka kebutuhan nutrisi untuk proses tumbuh kembang janin menjadi terhambat, akibatnya melahirkan bayi BBLR (Depkes RI, 2008).

Hasil Riskesdas 2007 menunjukkan prevalensi WUS yang beresiko KEK di Indonesia sebesar $13,6 \%$ dengan prevalensi yang terdapat di provinsi Riau sebesar 10,1\%. Hasil penelitian Nur Khasanah (2010) menggunakan data sekunder Riskesdas 2007 didapat prevalensi ibu hamil yang beresiko KEK,di Indonesia sebesar $21,6 \%$ dengan prevalensi yang terdapat di provinsi Riau sebesar $11,8 \%$. Hal ini mengindikasikan KEK pada ibu hamil masih menjadi masalah di Indonesia (Kemenkes, 2007).

Ibu hamil di Kota Pekanbaru Propinsi Riau yang memiliki lingkar lengan atas kurang 23,5 cm yang tertinggi yaitu di Kecamatan Payung Sekaki sebanyak 180 orang (8\%) (Profil Kesehatan Provinsi Riau, 2012). Sementara untuk tahun 2013 sebanyak 155 orang $(6,5 \%)$ terjadi sedikit penurunan.

Berdasarkan data dan fakta-fakta yang diperoleh tentang masalah gizi serta kaitan dengan penyebabnya serta latar belakang diatas maka peneliti tertarik untuk melakukan penelitian untuk mengetahui apakah ada hubungan asupan energi dan paritas terhadap resiko KEK pada ibu hamil di Kecamatan Payung Sekaki Kota Pekanbaru.

Tujuan penelitian ini adalah untuk mengetahui hubungan antara asupan energi dan paritas terhadap resiko KEK pada Ibu Hamil di Kecamatan Payung Sekaki Kota Pekanbaru.

\section{TINJAUAN PUSTAKA}

\subsection{Gizi Ibu Hamil}

Kebutuhan gizi selama ibu hamil meningkat karena selain diperlukan untuk memenuhi kebutuhan gizi ibu juga diperlukan untuk janin yang dikandungnya. Pemenuhan gizi selama hamil juga diperlukan untuk persiapan ASI serta tumbuh kembang bayi. Salah satu indikator terpenuhinya kebutuhan gizi selama hamil adalah adanya penambahan berat badan ibu.

Keadaan gizi ibu sebelum dan selama hamil mempengaruhi status gizi ibu dan bayi. Pertumbuhan dan perkembangan janin sangat dipengaruhi oleh asupan gizi ibu, karena kebutuhan 
gizi janin berasal dari ibu. Berbagai resiko dapat terjadi jika ibu mengalami kurang gizi, diantaranya perdarahan, abortus, BBLR, bayi lahir mati, kelainan kongenital, retardasi mental dan sebagainya (Sulistyoningsih,2001)

\subsection{Kebutuhan Gizi Ibu Selama Hamil}

Berikut ini beberapa kebutuhan gizi yang harus terpenuhi untuk ibu hamil yaitu :

1. Energi

Menurut Angka Kecukupan Gizi tahun 2012, penambahan kebutuhan energi per hari bagi ibu hamil pada trimester I 180 kkal, trimester II dan III masing-masing 300 kkal. Asupan gizi pada trimester I diperlukan untuk perkembangan dan pertumbuhan plasenta yang berguna untuk menyalurkan makanan dan pembentukan hormon, pada janin diperlukan pembentukan organ dan pertumbuhan janin dan badan. Asupan gizi pada trimester II diperlukan untuk pertumbuhan kepala, badan dan tulang janin. Sementara pertumbuhan janin dan plasenta serta cairan amnion akan berlangsung cepat pada trimester III (Sulistyoningsih, 2011).

2. Protein

Ibu hamil memerlukan konsumsi protein lebih banyak dari biasanya. Berdasarkan angka kecukupan gizi tahun 2012, selama hamil ibu memerlukan tambahan protein sebesar $20 \mathrm{gr} / \mathrm{hari}$. (Sulistyoningsih, 2011).

3. Karbohidrat

Janin memerlukan 40 gram glukosa/hari yang akan digunakan sebagai sumber energi. Karbohidrat merupakan sumber utama untuk tambahan kalori yang dibutuhkan selama kehamilan. Pertumbuhan dan perkembangan janin selama dalam kandungan membutuhkan karbohidrat sebagai sumber kalori utama. (Kristiyanasari, 2010).

\section{Lemak}

Lemak dibutuhkan tubuh terutama untuk membentuk energi serta perkembangan sistem syaraf janin. Oleh karena itu, ibu hamil tidak boleh sampai kurang mengkonsumsi lemak tubuh. Ibu hamil dianjurkan makan makanan yang mengandung lemak tidak lebih dari 25\% dari seluruh kalori yang dikonsumsi sehari. (Kristiyanasari, 2010).

\section{Vitamin}

Vitamin dibutuhkan untuk memperlancar proses biologis yang berlangsung dalam tubuh ibu hamil dan janin yaitu Vitamin A,Vitamin B1 dan B2,Vitamin B12, Vitamin C, : Vitamin D, Vitamin Edengan kebutuhannya 15 mg, Asam folat (Istiany, 2013).

6. Mineral

Beberapa mineral yang penting bagi ibu hamil adalah : zat besi, iodium dan kalsium.

\subsection{KEK Pada Ibu Hamil}

\subsubsection{Pengertian Kekurangan Energi Kronis (KEK)}

KEK adalah keadaan ibu yang menderita keadaan kekurangan makanan yang berlangsung menahun (kronis) sehingga mengakibatkan timbulnya gangguan kesehatan pada ibu. KEK dapat terjadi pada wanita usia subur dan pada ibu hamil (bumil). Seseorang dikatakan berisiko KEK adalah jika LILA kurang 23,5 cm (Wiboworini, 2007).

\subsubsection{Faktor Faktor yang Berpengaruh dengan Resiko KEK}

a. Asupan energi

Kehamilan menyebabkan meningkatnya metabolisme energi, karena itu kebutuhan energi dan zat gizi lainnya meningkat selama kehamilan. Peningkatan energi dan zat gizi tersebut diperlukan untuk pertumbuhan dan perkembangan janin, organ kandungan, perubahan komposisi dan metabolisme tubuh ibu. Sehingga kekurangan zat gizi tertentu yang diperlukan saat hamil dapat menyebabkan janin tumbuh tidak sempurna (Kristiyanasari, 2010).

b. Pekerjaan

Pekerjaan seseorang akan menggambarkan aktivitas dan kesejahteraan ekonomi yang akan didapatkan. Hasil penelitian juga menunjukkan bahwa ibu yang bekerja mempunyai pengetahuan yang lebih baik dari pada ibu yang tidak bekerja, karena pada ibu bekerja akan lebih banyak memiliki kesempatan untuk berinteraksi dengan orang lain (Sulistyawati, 2013).

c. Umur

Menurut Depkes (2001) pada ibu hamil dengan umur $<20$ tahun, rahim dan pinggul belum tumbuh mencapai ukuran dewasa. Akibatnya, ibu hamil pada usia ini mungkin mengalami persalinan lama, atau 
gangguan lainnya karena ketidaksiapan ibu untuk menerima tugas dan tanggung jawabnya sebagai orang tua. Sedangkan ibu hamil dengan umur > 35 tahun kesehatan ibu sudah menurun, akibatnya ibu hamil pada usia ini mempunyai kemungkinan lebih besar untuk mempunyai anak cacat, persalinan lama dan pendarahan.

\section{d. Paritas}

Paritas adalah jumlah anak yang pernah dilahirkan oleh ibu baik lahir hidup maupun mati. Menurut Depkes (2001) seorang ibu yang sedang hamil, keadaan rahimnya teregang oleh janin. Bila terlalu sering melahirkan, rahim akan semakin lemah. Jika ibu telah melahirkan anak lebih dari 4 orang, maka perlu diwaspadai adanya gangguan pada waktu kehamilan, persalinan dan nifas. Jumlah kehamilan yang terlalu sering menyebabkan resiko sakit dan kematian pada ibu hamil dan bayi. Selain itu, kemungkinan ibu yang sering melahirkan menyebabkan rendahnya status gizi.

e. Pendapatan

Ekonomi seseorang mempengaruhi dalam pemilihan makanan yang akan dikonsumsi sehari-harinya . Seorang dengan ekonomi tinggi yang kemudian hamil maka kemungkinan besar gizi yang dibutuhkan tercukupi ditambah lagi adanya pemeriksaan yang rutin membuat gizi ibu semakin terpantau (Kristiyanasari, 2010).

f. Pendidikan

Tingkat pendidikan ibu hamil sangat berperan dalam kualitas perawatan bayinya. Informasi yang berhubungan dengan perawatan kehamilan sangat dibutuhkan, sehingga akan meningkatkan pengetahuannya.Penelitian

menunjukkan bahwa semakin tinggi pendidikan ibu hamil semakin baik juga pengetahuannya tentang kehamilan (Sulistyawati, 2013)

g. Pengetahuan

Pengetahuan yang dimiliki oleh seorang ibu akan mempengaruhi dalam pengambilan keputusan dan juga akan berpengaruh pada prilakunya. Ibu dengan pengetahuan gizi yang baik, kemungkinan akan memberikan gizi yang cukup bagi bayinya terutama pada masa awal kehamilan. Walaupun dalam kondisi demikian jika seseorang memiliki pengetahuan yang baik maka ia akan berupaya untuk memenuhi kebutuhan gizinya dan juga bayinya (Chomaria, 2012).

\section{h. Jumlah Keluarga}

Menurut Azma (2003) pada status ekonomi rendah keluarga dengan jumlah anggota keluarga besar tentu berbeda dari jumlah anggota keluarga kecil dalam pemerataan makanan. Keluarga dengan jumlah anak besar dan jarak kelahiran yang dekat akan menimbulkan masalah. Pendapatan dalam keluarga pas-pasan dan mempunyai keluarga besar maka pemerataan dan kecukupan makanan dalam keluarga kurang sehingga dapat menyebabkan kekurangan gizi. Kekurangan gizi pada wanita makin bertambah apabila ada pendapat bahwa makanan lebih diutamakan pada pria atau bapak yang menafkahi dalam keluarga.

i. Pelayanan kesehatan

Peningkatan akses pelayanan kesehatan merupakan salah satu yang mempengaruhi tingkat kematian maternal dan tingkat kematian bayi. Untuk mewujudkan peningkatan derajat dan status kesehatan penduduk, ketersediaan dan keterjangkauan fasilitas dan sarana kesehatan merupakan salah satu faktor penentu utama. Hal ini berkaitan dengan upaya menurunkan angka kematian bayi dan kematian ibu, dimana pemerintah mengupayakan agar para ibu hamil dapat melahirkan dengan selamat demikian pula bayi yang dilahirkan dapat terlahir dengan sehat (Mulyaningrum, 2009).

\subsection{Pengukuran LILA (Lingkar Lengan Atas) \\ 2.6.1. Pengertian LILA}

Pengukuran lingkar lengan atas adalah suatu cara untuk mengetahui resiko KEK wanita usia subur termasuk remaja putri. Pengukuran LILA tidak dapat digunakan untuk memantau perubahan status gizi dalam jangka pendek (Supariasa, 2012).

\subsubsection{Tujuan Pengukuran LILA}

a. Mengetahui resiko kekurangan energi kronis pada wanita usia subur, baik ibu hamil maupun calon ibu, untuk menapis wanita yang mempunyai resiko melahirkan berat bayi lahir rendah.

b. Meningkatkan perhatian dan kesadaran masyarakat agar lebih berperan dalam pencegahan dan 
penanggulangan kekurangan energi kronis.

c. Mengembangkan gagasan baru dikalangan masyarakat dengan tujuan meningkatkan kesejahteraan ibu dan anak.

d. Meningkatkan peran petugas lintas sektoral dalam upaya perbaikan gizi wanita usia subur yang menderita kekurangan energi kronis.

e. Mengarahkan pelayanan kesehatan pada kelompok sasaran wanita usia subur yang menderita kekurangan energi kronis (Supariasa, 2012).

\subsubsection{Cara Mengukur LILA}

Menurut Supariasa dilakukan melalui urut-urutan telah ditetapkan. Ada 7 urutan pengukuran lingkar lengan atas yaitu:
a. Tetapkan posisi bahu dan siku
b. Letakkan pita antara bahu dan siku
c. Tentukan titik tengah lengan
d. Lingkarkan pita LILA pada tengah lengan
e. Pita jangan terlalu ketat
f. Pita jangan terlalu longgar
g. Baca skala dengan benar

\subsection{Metode Food Recall 24 Jam}

Prinsip dari metode recall 24 jam, dilakukan dengan mencatat jenis dan jumlah bahan makanan yang dikonsumsi pada periode 24 jam yang lalu.

Berikut langkah-langkah pelaksanaan recall 24 jam yaitu:

a. Meminta responden mengingat kembali semua makanan dan minuman selama 24 jam.

b. Deskripsi lengkap dari masingmasing makanan dan minuman tersebut termasuk metode memasak dan merek makanan (jika memungkinkan)

c. Mengestimasi jumlah dari makanan dan minuman yang telah dikonsumsi dalam ukuran rumah tangga.

d. Mengulang dan memastikan kembali semua daftar makanan dan minuman yang telah dibuat, termasuk penggunaan suplemen, vitamin, mineral secara benar (Supariasa, 2012).

Kelebihan metode food recall 24 jam : a. Mudah melaksanakannya serta tidak terlalu membebani responden

b. Biaya relatif murah, karena tidak memerlukan peralatan khusus dan tempat yang luas untuk wawancara.

c. Cepat, sehingga dapat mencakup banyak responden.

d. Dapat digunakan untuk responden buta huruf.

e. Dapat memberikan gambaran nyata yang benar-benar dikonsumsi individu sehingga dapat dihitung intake gizi sehari.

Kekurangan metode

food recall 24 jam :

a. Tidak dapat menggambarkan asupan makanan sehari-hari, bila hanya dilakukan recall satu hari.

b. Ketepatannya sangat tergantung pada daya ingat responden.

c. The flat slope syndrome, yaitu kecenderungan bagi responden yang kurus untuk melaporkan konsumsinya lebih banyak (over estimate) dan bagi responden yang gemuk cenderung melaporkan lebih sedikit (under estimate).

d. Membutuhkan tenaga atau petugas yang terlatih dan terampil dalam menggunakan alat-alat bantu ukuran dan ketepatan alat bantu yang dipakai menurut kebiasaan.

e. Responden harus diberi motivasi dan penjelasan tentang tujuan dari penelitian.

f. Untuk mendapatkan gambaran konsumsi sehari-hari recall jangan dilakukan pada saat panen, hari pasar, hari akhir pekan, dan lainlain (Supariasa, 2012).

\section{Metodologi Penelitian}

Jenis penelitian ini adalah penelitian analitik dengan desain penelitian yaitu cross sectional. Penelitian ini menggunakan variabel independent yaitu asupan energi dan paritas. Variabel dependent yaitu resiko KEK pada ibu hamil. Penelitian ini dilaksanakan di Kecamatan Payung Sekaki Kota Pekanbaru.

Populasi dalam penelitian ini adalah semua ibu hamil yang terdapat di Kecamatan Payung Sekaki Kota Pekanbaru yaitu 1599 ibu hamil (Data ibu hamil di puskesmas Payung Sekaki Agustus 2013-Maret 2014).

Sampel diambil dengan menggunakan rumus Estimating $a$ 
Population Proportion With Specified Absolute Precision dengan menggunakan efek rancangan 1,5 maka diperoleh sampel ibu hamil $137 \mathrm{ibu}$ hamil. Selanjutnya pengambilan sampel dilakukan secara Multistage Cluster Sampling.

\section{Analisis Data}

Analisis data dianalisa secara komputerisasi. Analisa univariat yang dilakukan terhadap tiap variabel. Analisis ini untuk mengetahui gambaran distribusi masing-masing variabel yang diteliti. Analisa bivariat menggunakan uji statistik chi-square untuk melihat ada atau tidaknya hubungan antara variabel independent dan dependent.

\section{HASIL DAN PEMBAHASAN}

Karakteristik Responden Penelitian:

Tabel 5.1

Distribusi Frekuensi Responden Berdasarkan Umur Ibu Hamil

\begin{tabular}{c|c|c}
\hline \multirow{2}{*}{ Umur } & \multicolumn{2}{|c}{ Jumlah } \\
\cline { 2 - 3 } Ibu Hamil & n & \% \\
\hline$<20$ tahun & 6 & 4,4 \\
20-35 tahun & 115 & 83,9 \\
$>35$ tahun & 16 & 11,7 \\
\hline Total & 137 & 100
\end{tabular}

Berdasarkan Tabel 5.1 dapat diketahui dari 137 responden ditemukan sebanyak 4,4\% dari golongan umur $<20$ tahun, 83,9\% dari golongan umur 20-35 tahun dan $11,7 \%$ dari golongan umur $>35$ tahun.

\section{Distribusi Frekuensi Responden Berdasarkan Usia Kehamilan \\ Tabel 5.2}

Distribusi Frekuensi Responden Berdasarkan Usia Kehamilan

\begin{tabular}{l|c|c}
\hline \multirow{2}{*}{ Usia Kehamilan } & \multicolumn{2}{|c}{ Jumlah } \\
\cline { 2 - 3 } & $\mathbf{n}$ & $\mathbf{\%}$ \\
\hline Trimester 1 & 39 & 28,5 \\
Trimester 2 & 51 & 37,2 \\
Trimester 3 & 47 & 34,3 \\
\hline Total & 137 & 100 \\
\hline
\end{tabular}

Berdasarkan Tabel 5.2 dapat diketahui dari 137 responden ditemukan sebanyak $28,5 \%$ dengan usia kehamilan trimester I, 37,2\% dengan usia kehamilan trimester II dan 34,3\% dengan usia kehamilan trimester III. Hasil penelitian menunjukkan bahwa usia kehamilan ibu hamilnya hampir merata antara trimester I, II dan III.

Distribusi Frekuensi Responden Berdasarkan Pendidikan

Tabel 5.3

Distribusi Frekuensi Responden Berdasarkan Pendidikan

\begin{tabular}{l|c|c}
\hline \multirow{2}{*}{ Pendidikan } & \multicolumn{2}{|c}{ Jumlah } \\
\cline { 2 - 3 } & $\mathbf{n}$ & $\mathbf{\%}$ \\
\hline SD & 8 & 5,8 \\
SMP & 22 & 16,1 \\
SMA & 96 & 70,1 \\
Pendidikan & 11 & 8 \\
& \multicolumn{2}{c}{100} \\
\hline \multicolumn{2}{c}{ Total Berdasarkan Tabel 5.3 dapat }
\end{tabular}

diketahui dari 137 responden ditemukan yang pendidikan tamat SD $5,8 \%$, SMP $16,1 \%$, SMA $70,1 \%$, dan Pendidikan Tinggi $8 \%$. Jadi dapat disimpulkan pendidikan responden yang terbanyak yaitu tamat SMA (70,1\%).

Distribusi Frekuensi Responden Berdasarkan Pekerjaan

Tabel 5.4

Distribusi Frekuensi Responden Berdasarkan Pekerjaan

\begin{tabular}{|l|c|c}
\hline \multirow{2}{*}{ Usia } & \multicolumn{2}{|c}{ Jumlah } \\
\cline { 2 - 3 } Kehamilan & n & \% \\
\hline IRT & 118 & 86,1 \\
PNS & 4 & 2,9 \\
Pegawai Swasta & 7 & 5,1 \\
Wiraswasta & 8 & 5,8 \\
\hline Total & 137 & 100 \\
\hline
\end{tabular}

Berdasarkan Tabel 5.4 dapat diketahui dari 137 responden ditemukan sebanyak $86,1 \%$ bekerja sebagai IRT, 2,9\% PNS, 5, $\%$ pegawai swasta dan 5,8\% wiraswasta. Jadi dapat disimpulkan pekerjaan responden yang terbanyak adalah sebagai IRT.

Analisa Univariat

Distribusi Frekuensi Responden Berdasarkan Asupan Energi Tabel 5.5

\begin{tabular}{l|c|c}
\hline \multirow{2}{*}{$\begin{array}{c}\text { Asupan } \\
\text { Energi }\end{array}$} & \multicolumn{2}{|c}{ Jumlah } \\
\cline { 2 - 3 } Cukup & n & \% \\
\hline Kurang & 18 & 13,1 \\
\hline Total & 119 & 86,9 \\
\hline
\end{tabular}

Berdasarkan Tabel 5.5 dapat diketahui bahwa distribusi responden berdasarkan asupan energi tidak merata, Dari 137 responden diketahui proporsi asupan energi berdasarkan kategori asupan cukup yaitu $13,1 \%$ dan asupan yang kurang 86,9 \%. Dapat disimpulkan 
responden yang asupan energi kurang lebih banyak dari pada responden yang asupan energi cukup.

Sumber energi utama yaitu kabohidrat dan ditambah dengan protein dan lemak. Asupan makanan yang kurang akan berpengaruh terhadap kecukupan kebutuhan energi. Jika hal ini terjadi dalam jangka waktu yang panjang akan mengakibatkan cadangan energi dalam tubuh terkuras sehingga menyebabkan status gizi kurang.

\begin{tabular}{|c|c|c|}
\hline \multicolumn{3}{|c|}{$\begin{array}{l}\text { Distribusi } \\
\text { Berdasarkan Paritas } \\
\text { Tabel 5.6. }\end{array}$} \\
\hline \multirow{2}{*}{ Paritas } & \multicolumn{2}{|c|}{ Jumlah } \\
\hline & $\mathbf{n}$ & $\%$ \\
\hline$<4$ & 132 & 96,4 \\
\hline$\geq 4$ & 5 & 3,6 \\
\hline Total & 137 & 100 \\
\hline
\end{tabular}

Berdasarkan Tabel 5.6 dapat diketahui bahwa distribusi responden berdasarkan paritas tidak merata, dari 137 responden diketahui proporsi responden yang memiliki paritas $<4$ (tidak beresiko KEK) yaitu 96,4\% dan paritas $\geq 4$ (beresiko KEK) 3,6\%. Dapat disimpulkan responden yang paritas $<4$ lebih banyak dari paritas $\geq$ 4.

Paritas mempengaruhi status gizi pada ibu hamil karena dapat mempengaruhi optimalisasi ibu maupun janin pada kehamilan yang dihadapi. Apabila makanannya tidak mencukupi selama kehamilan maka ibu hamil rentan gizi kurang. Hal ini karena pada saat hamil membutuhkan zat gizi yang lebih banyak.

\section{Distribusi Frekuensi Responden Berdasarkan Resiko KEK}

\begin{tabular}{c|c|c}
\hline \multirow{2}{*}{ Resiko KEK } & \multicolumn{2}{|c}{ Jumlah } \\
\cline { 2 - 3 } & $\mathbf{n}$ & $\mathbf{\%}$ \\
\hline Tidak beresiko & 73 & 53,3 \\
\hline Beresiko KEK & 64 & 46,7 \\
\hline Total & 137 & 100 \\
\hline
\end{tabular}

Berdasarkan Tabel 5.7 dapat diketahui bahwa distribusi responden berdasarkan resiko KEK hampir merata, dari 137 responden diketahui proporsi responden yang tidak beresiko KEK yaitu 53,3\% dan beresiko KEK 46,7\%. Jadi responden yang tidak beresiko KEK lebih banyak dari pada yang beresiko KEK.

Namun pengukuran LILA tidak dapat digunakan untuk memantau perubahan status gizi dalam jangka pendek.

\section{Analisa Bivari}

\section{Hubungan Asupan Energi Dengan Kejadian Resiko KEK}

Tabel 5.8.

Hubungan Asupan Energi Dengan Resiko KEK

\begin{tabular}{|c|c|c|c|c|c|c|c|}
\hline \multirow{3}{*}{$\begin{array}{c}\text { Asupan } \\
\text { energi }\end{array}$} & \multicolumn{4}{|c|}{ Resiko KEK } & \multirow{2}{*}{\multicolumn{2}{|c|}{ Total }} & \multirow{3}{*}{$\begin{array}{c}\mathbf{p} \\
\text { Valut }\end{array}$} \\
\hline & \multicolumn{2}{|c|}{\begin{tabular}{|c|} 
Tidak Beresiko \\
KEK
\end{tabular}} & \multicolumn{2}{|c|}{$\begin{array}{l}\text { Beresiko } \\
\text { KEK }\end{array}$} & & & \\
\hline & $\mathrm{n}$ & $\%$ & $\mathrm{n}$ & $\%$ & $\mathrm{n}$ & $\%$ & \\
\hline Cukup & 16 & 88,9 & 2 & 11,1 & 18 & 100 & \multirow{3}{*}{0,003} \\
\hline Kurang & 57 & 47,9 & 62 & 52,1 & 119 & 100 & \\
\hline Total & 73 & 53,3 & 64 & 46,7 & 137 & 100 & \\
\hline
\end{tabular}

Berdasarkan Tabel 5.8 bahwa responden yang asupan energi kurang sebanyak $52,1 \%$ yang beresiko KEK dan $47,9 \%$ yang tidak beresiko KEK. Dan asupan yang cukup sebanyak $88,9 \%$ tidak beresiko KEK dan 11,1\% beresiko KEK. Hasil uji statistik ChiSquare menunjukkan bahwa ada hubungan antara asupan energi dengan resiko KEK dengan $\mathrm{p}$ value $<0,05$. Ini menunjukkan bahwa ada hubungan yang signifikan antara dua variabel tersebut.

Faktor yang dapat mempengaruhi terjadinya kekurangan energi kronis atau gizi kurang pada ibu hamil adalah asupan energi yang kurang sebelum dan selama kehamilan. Ibu hamil yang mengkonsumsi makanan dengan jumlah kalori dibawah kecukupan yang dianjurkan dalam jangka waktu lama akan beresiko KEK, yang pada akhirnya dapat melahirkan bayi BBLR. Hal ini dapat dilihat dari LILA $<23,5 \mathrm{~cm}$. Gambaran keadaan jaringan otot dan lapisan lemak bawah kulit digunakan untuk mendeteksi resiko KEK pada ibu hamil dengan pengukuran LILA (Gibson, 2005)

Berdasarkan

hasil juga didapatkan ibu hamil yang asupan energi kurang yang tidak beresiko KEK sebanyak 47,9\%. Hal ini disebabkan oleh banyak faktor yang saling terkait. Resiko KEK merupakan akibat asupan energi kurang yang tidak adekuat dalam jangka yang lama sebelum hamil. Selain itu juga dipengaruhi oleh status gizi sebelum hamil. 
Kemudian asupan energi ibu hamil yang kurang terlihat dari pola makannya yang tidak teratur. Dimana hampir sebagian ibu hamil dengan pola makan hanya 2 kali makan utama dengan 1 kali selingan. Selain itu jadwal makanya yang juga tidak teratur, Hal ini terlihat dari seringnya tidak sarapan pagi sebelum melakukan aktivitas. Porsi makan untuk satu kali makan juga kurang dan tidak menu seimbang, sehingga kebutuhan untuk satu hari tidak tercukupi. Pada saat hamil terjadi peningkatan kebutuhan zat gizi. Berdasarkan angka kecukupan zat gizi 2012 penambahan energi untuk ibu hamil trimester I $180 \mathrm{kkal}$, trimester II dan III masing-masing 300 kkal (WNPG, 2012).

Hasil penelitian ini sejalan dengan penelitian Albugis (2008) yang menunjukkan adanya hubungan antara asupan energi dengan resiko KEK pada ibu hamil. Selain itu juga hasil penelitian Priswanti (2004), Krisnawati (2010) dan Surasih (2005) yang menyatakan adanya hubungan asupan energi dengan kejadian resiko KEK pada ibu hamil.

Hasil penelitian ini tidak sejalan dengan penelitian Srimulyaningrum (2009) yang menyatakan tidak adanya hubungan antara asupan energi dengan resiko KEK pada ibu hamil.

\section{Hubungan Paritas Dengan Kejadian Resiko KEK}

Tabel 5.9.

\begin{tabular}{|c|c|c|c|c|c|c|c|}
\hline \multirow{3}{*}{ Parita } & \multicolumn{4}{|c|}{ Resiko KEK } & \multirow{2}{*}{\multicolumn{2}{|c|}{ Total }} & \multirow{3}{*}{$\underset{\text { Value }}{\mathbf{p}}$} \\
\hline & \multicolumn{2}{|c|}{$\begin{array}{c}\text { Tidak } \\
\text { Beresiko }\end{array}$} & \multicolumn{2}{|c|}{$\begin{array}{c}\text { Beresik } \\
\text { KEK }\end{array}$} & & & \\
\hline & $\mathrm{n}$ & $\%$ & $\mathrm{n}$ & $\%$ & $\mathrm{n}$ & $\%$ & \\
\hline$<4$ & 69 & 52,3 & 6 & 47, & 13 & 10 & \\
\hline$\geq 4$ & 4 & 80 & 1 & 20 & 5 & 10 & 0,371 \\
\hline Total & 73 & 53,3 & 6 & 46 , & 13 & 10 & \\
\hline
\end{tabular}

Berdasarkan Tabel 5.9 bahwa responden yang mempunyai paritas $\geq 4$ ada sebanyak $20 \%$ yang beresiko KEK dan $80 \%$ yang tidak beresiko KEK. Hasil uji statistik Chi-Square menunjukkan bahwa tidak ada hubungan antara paritas dengan resiko KEK dengan $\mathrm{p}$ value $>0,05$. Ini menunjukkan bahwa tidak ada hubungan yang signifikan antara dua variabel tersebut.

Berdasarkan hasil juga didapat ibu hamil yang paritas $\geq 4$ yang tidak beresiko KEK $80 \%$. Hal ini disebabkan bahwa paritas mempengaruhi secara tidak langsung terhadap resiko KEK pada ibu hamil. Namun banyak faktor lain yang menyebabkan terjadinya KEK pada ibu hamil yaitu penyakit infeksi, pendidikan, pengetahuan, pendapatan, jumlah keluarga, umur ibu, pekerjaan dan pelayanan kesehatan.

Kemudian dari 5 orang responden yang paritas $\geq 4$ hanya $20 \%$ yang beresiko KEK dan $80 \%$ orang tidak beresiko KEK. Hal ini disebabkan oleh faktor jarak kehamilan, jarak kehamilan yang tidak terlalu dekat atau di bawah 2 tahun dapat mengurangi resiko KEK. Responden yang beresiko KEK tersebut mempunyai anak 5 orang. Anak pertama berumur 9 tahun dengan jarak kehamilan dengan kehamilan sebelumnya yaitu hanya lebih kurang 1 tahun begitu juga dengan kehamilan yang ke 3, 4, dan 5 .

Apabila konsumsi makanan ibu hamil kurang dari yang dibutuhkan, maka cadangan zat gizi di dalam tubuh ibu akan digunakan untuk menutupi kekurangan tersebut. Jika kehamilan berikutnya berdekatan dengan kehamilan sebelumnya, maka ibu tidak mempunyai cukup waktu untuk mengembalikan cadangannya dan akan berpotensi menyebabkan terjadinya gizi kurang (Departemen Gizi \& Kesehatan, 2007)

Jarak kelahiran yang lebih pendek tidak memungkinkan waktu yang cukup bagi ibu untuk mengembalikan tingkat cadangan nutrisi yang diperlukan bagi perkembangan tubuh ibu dan janin. Selain itu akan menjadi beban tambahan pada tubuh ibu, tidak ada waktu yang cukup diantara kehamilan yang menyebabkan ibu tidak mampu untuk mengganti simpanan zat gizi dalam tubuh . Hal ini akan membuat ibu rentan terhadap gizi kurang (Turhayati, 2006).

Hal ini sesuai dengan penelitian Albugis (2008) dan Agustian (2010) yaitu tidak adanya hubungan antara paritas dengan resiko KEK pada ibu hamil. Selain itu juga sejalan dengan penelitian yang dilakukan Khasanah (2010) dengan analisa data riskesdas 
2007 didapat hasil bahwa paritas tidak berhubungan dengan resiko KEK pada ibu hamil.

Hasil penelitian ini tidak sejalan dengan penelitian Azma (2003) yang menyatakan adanya hubungan antara paritas dengan resiko KEK pada ibu hamil. Selain itu juga didukung oleh penelitian Yuliani 2004 yang menyatakan ada hubungan yang signifikan antara paritas dengan kejadian KEK pada ibu hamil.

\section{KESIMPULAN}

1. Asupan energi responden sebanyak 13,1 \% cukup dan 86,9\% kurang.

2. Paritas responden sebanyak $96,4 \%<$ 4 (tidak beresiko KEK) dan 3,6\% $\geq$ 4 (beresiko KEK).

3. Resiko KEK responden sebanyak 53,3\% yang tidak beresiko KEK dan $46,7 \%$ beresiko KEK.

4. Ada hubungan antara asupan energi dengan resiko KEK ( $\mathrm{p}$ value $<$ $0,05)$.

5. Tidak ada hubungan antara paritas dengan resiko KEK ( $\mathrm{p}$ value $>0,05)$.

\section{SARAN}

1. Untuk ibu hamil agar dapat mengatur pola makan dengan 3 kali makan utama dan 2 kali selingan serta porsi makan harus lebih banyak dari pada sebelum hamil.

2. Petugas kesehatan hendaknya memberikan penyuluhan dan informasi pada ibu hamil tentang gizi seimbang dan pola makan yang baik untuk ibu hamil.

3. Perlunya dilakukan penelitian lebih lanjut tentang pola makan ibu hamil yang beresiko KEK.

\section{DAFTAR PUSTAKA}

Almatsier, S. 2001. Prinsip Dasar Ilmu Gizi. Jakarta : PT Gramedia Pustaka Utama.

Almatsier, S. 2011. Gizi Seimbang Dalam Daur Kehidupan. Jakarta : PT Gramedia Pustaka Utama.

Albugis, D. 2008. Faktor-Faktor yang Berhubungan Kurang Energi Kronis pada Ibu Hamil di wilayah Puskesmas Jembatan Serong Kecamatan Pancoran Mas Depok Jawa Barat 2008 (Analisis Data Sekunder). FKM UI.
Apriadji, WH. 1986. Gizi Keluarga. Jakarta : PT Penebar Swadaya.

Arisman, 2004. Gizi Dalam Daur Kehidupan. Jakarta : Buku Kedokteran EGC.

Arisman, 2009. Gizi Dalam Daur Kehidupan. Jakarta : Buku Kedokteran EGC.

Azma, N. 2003. Faktor-Faktor yang Berhubungan dengan Kejadian Ibu Hamil Resiko KEK Di Kota Sukabumi Tahun 2002. Depok : FKM UI

Chomaria, N. 2012. Makanan Sehat Seimbang Bagi Ibu Hamil. Jakarta : PT Elex Media Komputindo.

Departemen Gizi dan Kesehatan Masya rakat FKM UI, 2007. Gizi dan K esehatan Masyarakat. Jakarta : PT Rajagrafindo Persada.

Depkes RI, 2001. Pedoman Pengenalan Tanda Bahaya pada Kehamilan, Persalinan dan Nifas. Jakarta : Depkes

Dinas Kesehatan Kota Pekanbaru. 2012. Profil Kesehatan Puskesmas Payung Sekaki Kecamatan Payung Sekaki Kota Pekanbaru Provinsi Riau.

Dinas Kesehatan Provinsi Riau. 2012. Profil Kesehatan Provinsi Riau.

Hardinsyah, 2000. Studi Analisis Faktor-Faktor Sosial, Ekonomi dan Biologi yang Mempengaruhi Kejadian KEK pada Ibu Hamil. Bogor : IPB

Istiany, A. 2013. Gizi Terapan. Bandung : PT Remaja Rosdakarya.

Institute of Medicine, 2005. Dietary Reference Intake for Energy, Carbohydrate, Fiber, Fat, Fatty Acids, Cholesterol, Protein, and Amino Acids. Washington, DC: National Academies Press.

Institute Of Medicine, 1990. Nutrition During Pregnancy. Washington, DC: National Academy Press.

Jannah, N. 2012. Buku Ajar Asuhan Kebidanan Kehamilan. Yogyakarta.CV.Andi Offset.

Krisnawati, N. 2010. Hubungan Tingkat Konsumsi pada Ibu Hamil dengan Kekurangan Energi Kronis Di Puskesmas Wonoayu Kabupaten Sidoarjo. FKM 
Kristiyanasari, W. 2010. Gizi Ibu Hamil. Yogyakarta : Ruha Medika.

Marlenywati, 2010. Resiko Kurang Energi Kronis pada Ibu Hamil Remaja Di Kota Pontianak Tahun 2010. FKM UI

Mitayani, 2010. Buku Saku Ilmu Gizi. Jakarta : CV.Trans Info Media.

Prawirohardjo, S. 2010. Ilmu Kebidanan. Jakarta : PT Bina Pustaka.

Priswanti, 2004. Hubungan Ketersediaan Pangan Keluarga dan Tingkat Konsumsi Energi Protein, Fe, Asam Folat, Vitamin $B_{12}$ dengan Kejadiaan KEK dan Anemia pada Ibu Hamil. Semarang : Fakultas Kedokteran Universitas Diponegoro.

Sibagariang, E. 2010. Gizi Dalam Kesehatan Reproduksi. Jakarta : CV.Trans Info Media.

Srimulyaningrum, 2009. Faktor-Faktor yang Berhubungan Dengan Resiko Kurang Energi Kronis pada Ibu Hamil di Propinsi DKI Jakarta(Analisis Data Riskesdas 2007). FKM UI

Suhardjo, 2007. Pangan dan Gizi Pertanian. Jakarta : UI Pres.

Sulistyawati, A. 2013. Asuhan Kebidanan Pada Masa Kehamilan. Jakarta : Salemba Medika.

Sulistyoningsih, H. 2011. Gizi Untuk Kesehatan Ibu dan Anak. Yogyakarta : Graha Ilmu.

Supariasa, 2012. Penilaian Status Gizi. Jakarta : Buku Kedokteran EGC.

Surasih, H. 2006. Faktor-Faktor yang Berhubungan dengan Kejadiaan KEK pada Ibu Hamil Di Kabupaten Banjarnegara Tahun 2005.

Suyanto, 2008. Masalah Gizi Balita. Jakarta : Papas Sinar. 